\title{
Ambient vertical flow in long-screen wells: a case study in the Fontainebleau Sands Aquifer (France)
}

\author{
J. A. Corcho Alvarado • F. Barbecot • R. Purtschert
}

\begin{abstract}
A tritium $\left({ }^{3} \mathrm{H}\right)$ profile was constructed in a longscreened well (LSW) of the Fontainebleau Sands Aquifer (France), and the data were combined with temperature logs to gain insight into the potential effects of the ambient vertical flow (AVF) of water through the well on the natural aquifer stratification. AVF is commonly taken into account in wells located in fracture aquifers or intercepting two different aquifers with distinct hydraulic heads. However, due to the vertical hydraulic gradient of the flow lines intercepted by wells, AVF of groundwater is a common process within any type of aquifer. The detection of ${ }^{3} \mathrm{H}$ in the deeper parts of the studied well (approximate depth $50 \mathrm{~m}$ ), where ${ }^{3} \mathrm{H}$-free groundwater is expected, indicates that shallow young water is being transported downwards through the well itself. The temperature $\operatorname{logs}$ show a nearly zero gradient with depth, far below the mean geothermal gradient in sedimentary basins. The results show that the age distribution of groundwater samples might be biased in relation to the age distribution in the surroundings of the well. The use of environmental tracers to investigate aquifer properties, particularly in LSWs, is then limited by the effects of the AVF of water that naturally occurs through the well.
\end{abstract}

Received: 9 October 2007 / Accepted: 1 October 2008

Published online: 29 October 2008

(C) Springer-Verlag 2008

\section{J. A. Corcho Alvarado (}

University Institute of Applied Radiation Physics,

Grand-Pré 1, 1007, Lausanne, Switzerland

e-mail: jose-antonio.corcho-alvarado@chuv.ch

Tel.: +41-21-6233481

Fax: +41-21-6233435

\section{J. A. Corcho Alvarado · F. Barbecot}

Laboratoire Interactions et Dynamique des Environnements de Surface, UMR 8148 IDES,

Université Paris-Sud

Bâtiment 504, 91405, Orsay Cedex, France

R. Purtschert

Climate and Environmental Physics, Physics Institute,

University of Bern,

Sidlerstrasse 5, CH-3012, Bern, Switzerland
Keywords Environmental tracers - Groundwater age · Long-screen well · France $\cdot$ Tritium

\section{Introduction}

Environmental tracer methods have been widely applied to investigate groundwater bodies in many different sites around the world. The method relies on the interpretation of the tracer concentration in groundwater in terms of aquifer properties such as, for example, the age distribution of groundwater. Most applied mathematical models simplify the natural processes affecting the tracer distribution in groundwater (Ekwurzel et al. 1994; Corcho Alvarado et al. 2005, 2007). In the models, it is assumed that the transit time distribution of the water sample adequately represents the age distribution of the flow lines within the aquifer and that they can be described by relatively simple analytical functions (e.g. lumped parameter models: Zuber 1986; and Zuber and Maloszewski 2001).

In numerous studies up to now, it has been assumed that wells provide a simple average of the vertical distribution of tracer or contaminant concentrations adjacent to the well screen (Zuber and Maloszewski 2001; Zhang and Fogg 2002; Ozyurt and Bayari 2003). However, recent works have shown that this situation is more the exception than the rule (Reilly et al. 1989; Church and Granato 1996; Elci et al. 2001; Zhang and Fogg 2002; Elci et al. 2003). These studies confirm that conventional monitoring wells yield composite samples that might mask the true vertical distribution of dissolved contaminants (or tracers) in the aquifer. The complexity of the concentration averages sampled from the wells depend on factors such as the length and vertical position of the screened interval (borehole conditions), the hydraulic conditions in the aquifer, the vertical distribution of the tracer in the vicinity of the well screen (Martin-Hayden and Robbins 1997), the sampling method (e.g. passive or active sampling, multiple level or full screen sampling, etc.) and the magnitude and direction of the ambient vertical flow (AVF) of water within the wells (Reilly et al. 1989; Elci et al. 2001, 2003). The effect of these factors will be particularly pronounced (1) where groundwater ages (or tracer concentrations) show strong gradients with depth; and (2) in wells with long screen intervals (>10 m). 
The second case is very common in studies of public water-supply wells, which have long screens for productivity purposes.

The question in how far the tracer or age distribution of a sample represents the situation in the surrounding aquifer has been addressed in previous investigations (e.g. Zuber and Maloszewski 2001; Maloszewski et al. 2004; Weissmann et al. 2002; Zinn and Konikow 2007), but little attention has been paid to the aspect of AVF within the well and its effects to the tracer distribution around the well. It is well known that a vertical water flow is naturally produced at the borehole location due to the vertical hydraulic gradient of the flow lines intercepted by the borehole. Commonly a downward component of the groundwater flow exists in recharge areas, and an upward component in discharge areas (Fetter 2001).

AVF has been considered in heterogeneous aquifers (e.g. fractured aquifers) or in boreholes intercepting two different aquifers with distinct hydraulic heads. However, AVF could also largely bias the original age stratification in relatively homogeneous aquifers (Zinn and Konikow 2007). A well is an open water-filled conduit with a very high hydraulic conductivity compared to the aquifer. This fast flow path has consequently important implications to the flow distribution in the surroundings of the well itself. Samples from wells with long screens might be ambiguous for quantifying the concentrations in, e.g. contaminant plumes. (Elci et al. 2001; Zinn and Konikow 2007).

The small fluxes of AVFs require sensitive flow meters (e.g. heat-pulse or electromagnetic flowmeters; Reilly et al. 1989). For example, AVFs between 0.01-6.2 L/min were measured in $73 \%$ of 142 monitoring wells from 16 sites across USA (Elci et al. 2001). In a well with a diameter of $0.3 \mathrm{~m}$, this range of fluxes would be equivalent to flow velocities of $0.15-130 \mathrm{~m} /$ day. In a short time scale, they produce little changes in the groundwater age stratification; but in a long-term one, the original stratification can be significantly distorted due to the large volume of water that could be transported through the well. For example, in a borehole with a vertical flux of $0.5 \mathrm{~L} / \mathrm{min}$, about $0.7 \mathrm{~m}^{3}$ of water per day would be transported from one section to another section of the borehole. As mentioned before, the magnitude of the problem would depend on the relative importance of the vertical with respect to the horizontal flow in the system; or, in other words, on the head distribution around the borehole.

The main objective of this report is then to focus on this problem which is commonly dismissed in tracer studies of groundwater systems. Simple field experiments, which combined measurements of the environmental tracer ${ }^{3} \mathrm{H}$ and of the water temperature, were performed to investigate the vertical flow of water in a well located in the unconfined Fontainebleau Sands Aquifer (south of Paris, France). Some sampling recommendations are presented which could help to reduce the influence of the ambient vertical water flow over the tracer measurements.

\section{Field site description}

The unconfined Oligocene Fontainebleau Sands Aquifer was selected for this investigation because it is hydrogeologically well known. This aquifer has been the subject of intensive tracer studies (Bariteau 1996; Schneider 2005; Corcho Alvarado et al. 2007). The aquifer is located in the shallower zone of the Paris Basin (France), which is the largest sedimentary basin of Western Europe (Fig. 1). It is embedded between two clayey layers: above is the Beauce formation (limestone, millstone and clay) and below are Oligocene and Eocene marls which separate the Fontainebleau Sands from the underlying Eocene multi-layered aquifer (Fig. 2). The upper part of the Fontainebleau sands formation is made of up to $99 \%$ of pure unconsolidated quartz sands (white facies), while the content of organic matter, carbonates, sulphides, feldspar and clays (dark facies) increases slightly with depth (Bariteau 1996). The Fontainebleau formation has a typical thickness of 50-70 m, an hydraulic transmissivity of $1^{\times} 10^{-3}-5 \times 10^{-3} \mathrm{~m}^{2} \mathrm{~s}^{-1}$ and a mean total porosity of about 25\% (Mégnien 1979; Mercier 1981; Ménillet 1988).

The hydrogeological situation is characterized by a spatially extended recharge at rates varying between 100 and $150 \mathrm{~mm} /$ year (Schneider 2005; Corcho Alvarado et al. 2007), and by groundwater tables laying between 20 and 45 meters below ground level ( $\mathrm{m} \mathrm{bgl})$. The groundwater head distribution is mainly a consequence of the topography, where water flows from the elevated plateaus to the lower valleys where groundwater discharges (Fig. 1). Possible leakage from the underlying Eocene aquifers to the Fontainebleau Sands can be excluded in the area of the present investigation, as the potentiometric surface of the Eocene aquifer is far below that of the Fontainebleau Aquifer preventing any upward seeping through the confining lower Oligocene (Schneider 2005).

Most of the production wells in the Fontainebleau Sands Aquifer have long screen intervals. The borehole SM was selected for the study for several reasons. The use of this well for water supply stopped more than 15 years ago, and the natural flow conditions have therefore reestablished, which, as this study is focused on natural conditions, is an important condition for this study. The age structure of the groundwater is well constrained with an exponential age distribution with a mean age of about 100 years (Corcho Alvarado et al. 2007). The well is located in an area with elevated piezometric heads (Fig. 1), and downward flow might be probable (Fetter 2001; Einarson 2005). The well has a long screen interval (ca. $27 \mathrm{~m}$, located between 26 and $53 \mathrm{~m} \mathrm{bgl}$ ), completely immersed in the sands formation. The inner diameter of the sampled screen is $0.6 \mathrm{~m}$. The water table is at about $20-25 \mathrm{~m} \mathrm{bgl}$, and the well is about $54 \mathrm{~m}$ deep.

\section{Methods}

\section{${ }^{3} \mathrm{H}$ activity in groundwater}

In a first set of experiments, groundwater samples from different depths within well SM were taken for tritium 


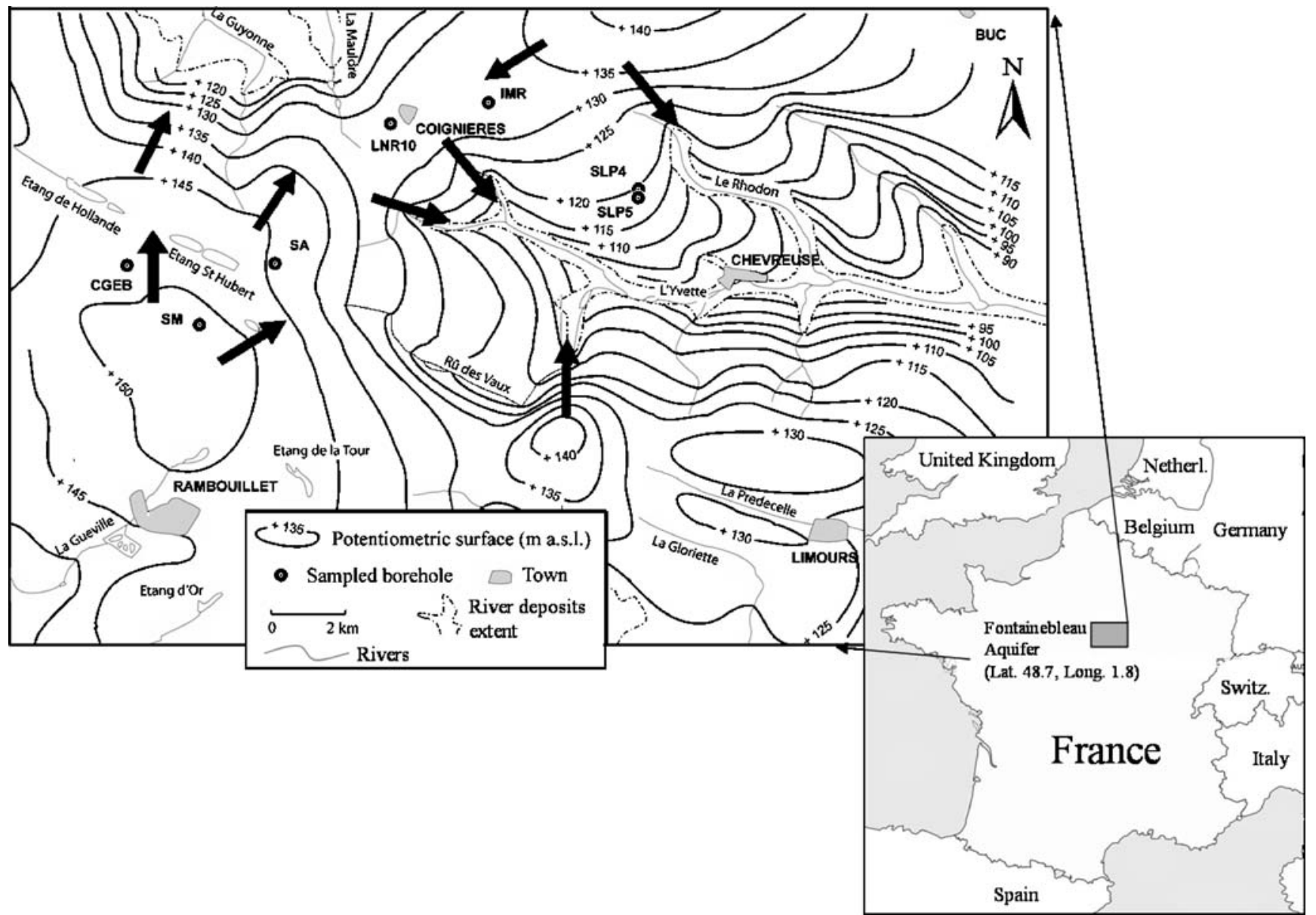

Fig. 1 Location of the study area showing the isopiezometric heads in the Fontainebleau Sands Aquifer (modified after Rampon 1965) and the location of the sampling well SM. Arrows indicate the most probable flow directions

analysis $\left({ }^{3} \mathrm{H}\right.$, half-life of 12.32 years $)$. A low-flow pumping approach (pumping rate $<2 \mathrm{~L} / \mathrm{min}$ ) was selected for the sampling in order to minimize distortion of the water column and to reduce a potential mixing of groundwater from different depth intervals. The ${ }^{3} \mathrm{H}$ measurements were performed by gas proportional counting at the Physics Institute of the University of Bern (Switzerland), after an electrolytic enrichment step.

The natural cosmogenic level of ${ }^{3} \mathrm{H}$ in precipitation is a few TU (Roether 1967); however, as a result of the atmospheric testing of thermonuclear bombs, high ${ }^{3} \mathrm{H}$ activities were introduced in the environment between 1951 and 1980. This anthropogenic contamination produced a maximum ${ }^{3} \mathrm{H}$ fallout in the mid-1960s (bomb peak), with an almost exponential decrease to present-day ${ }^{3} \mathrm{H}$ fallout levels of about $10 \mathrm{TU}$. Hence, this radionuclide has been intensively used for tracing young groundwater (groundwater that recharged over the past 40-50 years).

Numerous methodologies have been developed for using this radioisotope in groundwater studies. ${ }^{3} \mathrm{H}$ concentrations above $0.2 \mathrm{TU}$ indicate the presence of water components which recharged after 1950. The peak shape of the ${ }^{3} \mathrm{H}$ fallout curve in precipitation results in ambiguous dating results. Thus, ${ }^{3} \mathrm{H}$ is commonly combined with its decay product ${ }^{3} \mathrm{He}$ (Schlosser et al. 1988;
Schlosser et al. 1989), which allows the determination of unique and precise ${ }^{3} \mathrm{H} /{ }^{3} \mathrm{He}$ ages of the young groundwater components. Another approach is based on obtaining long-term records of ${ }^{3} \mathrm{H}$ in groundwater, which also provides better constraints to the groundwater age (Zuber and Maloszewski et al. 2001). Some studies are based on the combination of ${ }^{3} \mathrm{H}$ with other young tracers like, for example, ${ }^{85} \mathrm{Kr}, \mathrm{SF}_{6}$ and $\mathrm{CFCs}$ in multiple tracer studies (Ekwurzel et al. 1994; Corcho Alvarado et al. 2005). The multiple tracer approach provides a better understanding of the processes that affects the tracer concentrations in groundwater. In the present study, measurements of ${ }^{3} \mathrm{H}$ in groundwater are combined with groundwater temperature data, in a kind of multiple tracer approach, to obtain information about the occurrence of vertical mixing within the well.

The ${ }^{3} \mathrm{H}$ fallout in the investigated area was reconstructed by averaging the ${ }^{3} \mathrm{H}$ fallout data reported for the monitoring stations located in Le Mans and Orleans-LaSource (data taken from IAEA/WMO 2001). A value of $5 \mathrm{TU}$ was assumed for fallout prior to the bomb tests (Roether 1967). The expected ${ }^{3} \mathrm{H}$ distribution in groundwater was then predicted by coupling an advectiondiffusion transport model for the unsaturated zone with a lumped parameter model for the saturated zone. 


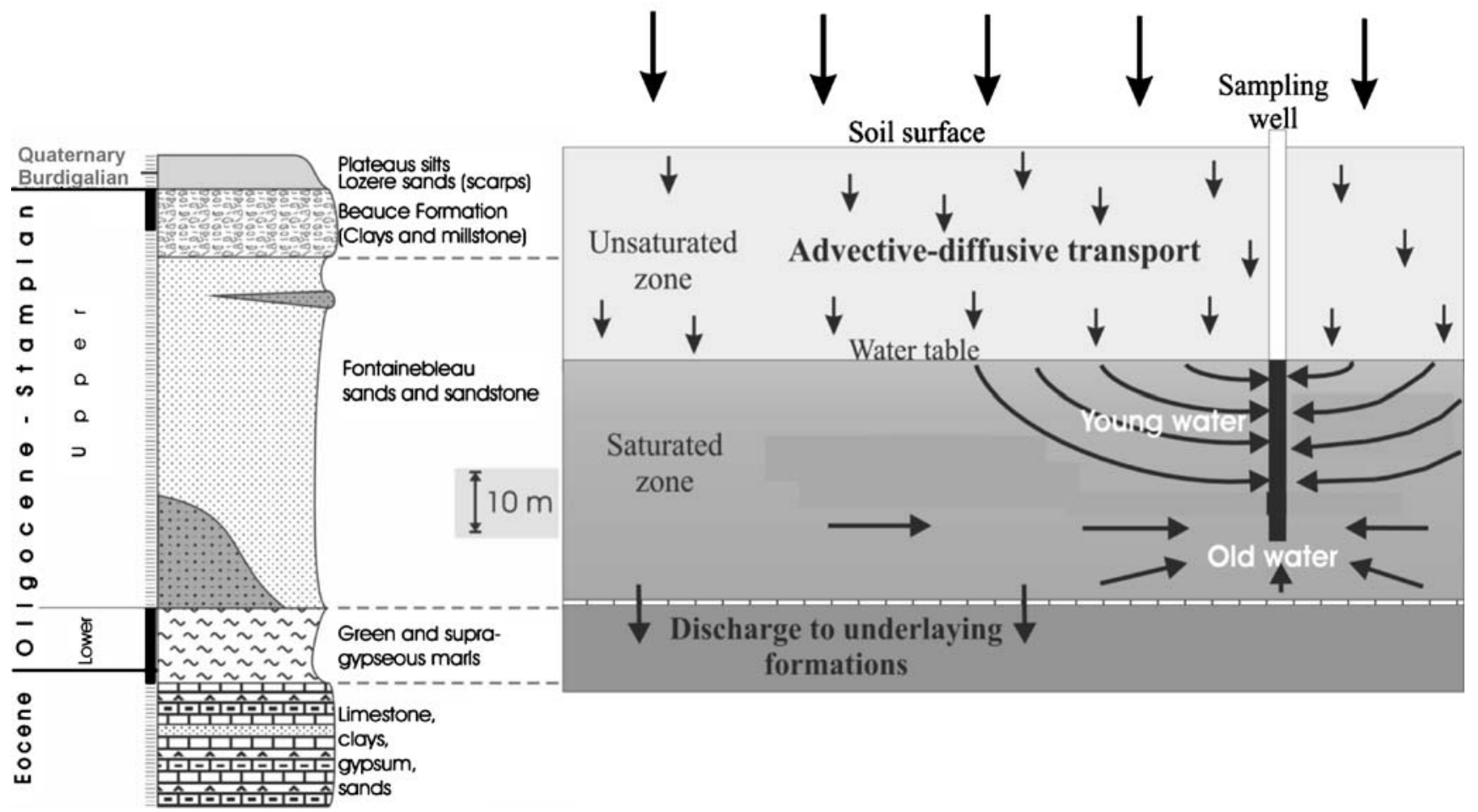

Fig. 2 Geological cross section of the aquifer (left), and schematic display of the applied conceptual model (right)

A one-dimensional advective diffusive decay transport model is used to describe the transport of ${ }^{3} \mathrm{H}$ through the thick unsaturated zone $(\sim 20-25 \mathrm{~m})$ that overlays the Fontainebleau Sands Aquifer (Cook and Solomon 1995; Corcho Alvarado et al. 2007), and to predict the temporal input of ${ }^{3} \mathrm{H}$ into groundwater. The model, as well as its validation, have been already described in a previous publication (Corcho Alvarado et al. 2007). The following parameters are used for the modeling: $10 \%$ for the water filled porosity and $25 \%$ for the total porosity (Mégnien 1979; Vernoux et al. 2001; Schneider 2005), a dispersivity of $0.1 \mathrm{~m}$ (Cook and Solomon 1995; Rueedi et al. 2005, Gaye and Edmunds 1996), a gas tortuosity of 0.6 (Millington 1959), a liquid tortuosity of 0.25 (Barraclough and Tinker 1982), a recharge rate of $150 \mathrm{~mm} /$ year (Mercier 1981; Bariteau 1996; Schneider 2005; Corcho et al. 2005) and a recharge depth of $25 \mathrm{~m}$ (depth of the water table near the borehole).

The temporal input of ${ }^{3} \mathrm{H}$ into groundwater, predicted with the advective-diffusive-decay transport model, is then used as an input function $\left(c_{\text {in }}\right)$ in the lumped parameter model (Eq. 1). The activity distribution of ${ }^{3} \mathrm{H}$ in groundwater, at the sampling date, is obtained applying the dispersion model (Zuber and Maloszewski 2001). This lumped parameter model is selected because it can be adapted to represent a large number of age distributions by simply tuning the dispersion parameter. The relation between the input $c_{\text {in }}$ and the output tracer concentration $c_{\text {out }}$ is given by the convolution integral:

$c_{\text {out }}(T)=\int_{0}^{\infty} c_{\text {in }}(T-t) \cdot e^{-\lambda t} \cdot \frac{\tau}{\sqrt{\pi \cdot d \cdot \tau^{3}}} \cdot e^{\frac{-(t-\tau)^{2}}{d \cdot \tau}} d t$

where $d$ is the dispersion parameter (years), $\tau$ is the mean residence time, $T$ is the sampling date, $\lambda$ is the decay constant of the radioisotope (years ${ }^{-1}$ ) and $t$ is the residence time of a water parcel.

The activity distributions of ${ }^{3} \mathrm{H}$ obtained with the dispersion model for two different dispersion parameters are depicted in the Fig. 3. The dispersion parameters selected for the modeling are within realistic values for sandy aquifers (Engesgaard et al. 1996). The modeled ${ }^{3} \mathrm{H}$ activities show a large variability with depth (Fig. 3). High concentration gradients can be expected in the depth range between $25-40 \mathrm{~m}$ bgl where two samples were taken for ${ }^{3} \mathrm{H}$ analyses (sampling depths 27 and $33 \mathrm{~m} \mathrm{bgl}$ ). An additional sample was taken at $47 \mathrm{~m} \mathrm{bgl}$, where a ${ }^{3} \mathrm{H}$ activity below detection limit is expected. Strong deviations between the modeled and measured values are an indication for vertical flow within the borehole. 


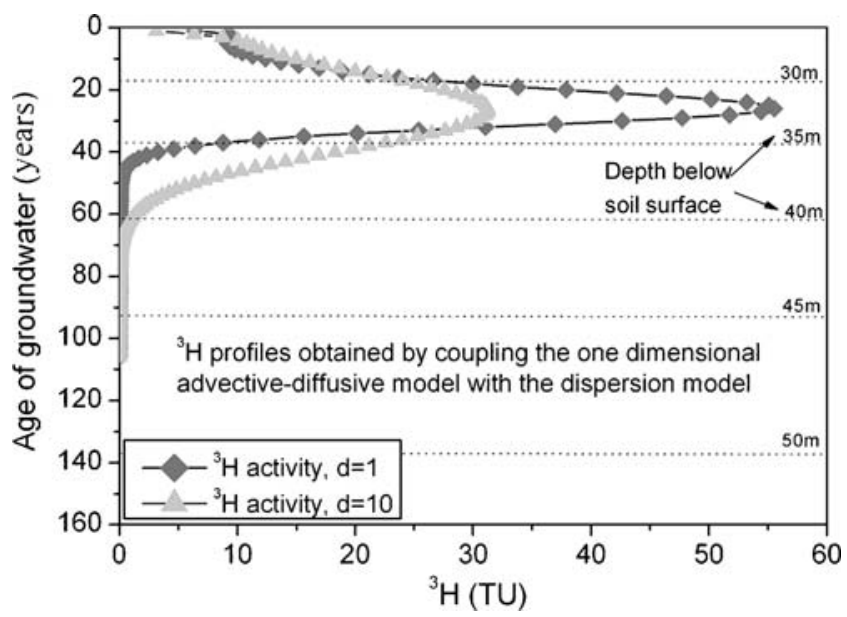

Fig. $3{ }^{3} \mathrm{H}$ activities in groundwater modeled with the dispersion model, for two different dispersion parameters $(d=1$ year and $d=10$ years), plotted as function of the groundwater age. The dotted lines represent the depths below the soil surface $(30,35,40,45$ and $50 \mathrm{~m})$

\section{Groundwater temperature}

In a second set of experiments, the groundwater temperature gradient within the long screen interval of well SM was investigated. In this study, a temperature sensor with a resolution of $0.005^{\circ} \mathrm{C}$, adequately calibrated, was used to obtain the groundwater temperature data. In order to reduce the distortion of the water column, the sensor was moved as slowly as possible within the well. The temperature measurements were carried out in two consecutive months (June and July 2006) by the IDES laboratory of the University of Paris XI (France).

Temperature logs provide very useful information on the movement of water through a well, including the location of depth intervals with elevated conductivity. Absence of vertical flow is indicated by a smooth and linear temperature increase with depth according to the local geothermal gradient, which depends on the thermal conductivity of the formation and the heat flow from lower strata. A thermal equilibrium between the water and the surrounding rocks is achieved within hours. A deviation of the temperature gradient in the borehole from the geothermal gradient in the rock matrix provides evidence for a vertical water flow (Price and Williams 1993). A smaller gradient is an indication for a downward flux and visa versa. In the area of investigation, a geothermal gradient of $3^{\circ} \mathrm{C} / 100 \mathrm{~m}$ can be assumed for the formations (BRGM 2005). This value is similar to the average geothermal gradient in French sedimentary basins of $3^{\circ} \mathrm{C} / 100 \mathrm{~m}$ (data taken from BRGM and ADEME (2005); BRGM 2005). The range of variation of the geothermal gradient in sedimentary basins $\left(1-5^{\circ} \mathrm{C} /\right.$ $100 \mathrm{~m}$ ) is also included in the interpretations (Pfister and Rybach 1996).

\section{Results and dicussion}

\section{${ }^{3} \mathrm{H}$ activities in groundwater}

The activities of ${ }^{3} \mathrm{H}$ are rather similar in all the groundwater samples analysed, with values between 5 and 6 TU (Fig. 4). According to the modelling results (Fig. 3), we would expect a peak and a decrease in depth with concentrations below the detection limit for the deepest sampling location where groundwater ages are on the order of a few hundreds of years (Corcho Alvarado et al. 2007). The ${ }^{3} \mathrm{H}$ activity of $5.3 \mathrm{TU}$ found in the groundwater sample taken from the bottom part of the screen (Fig. 4) indicates the presence of relatively young groundwater in this depth section of the well. This, and the lack of a concentration peak, are explained by a downward vertical flow of water through the well. Recharge rates estimated based on low-flow pumping or diffusion samplers (passive sampling; Sanford et al. 1996) will therefore overestimate the in situ value within the aquifer.

\section{Groundwater temperature}

The groundwater temperature profiles measured in June and July 2006 in the well SM of the Fontainebleau Sands Aquifer are shown in the Fig. 4. In both field campaigns the water temperatures showed a slight change with depth with a mean gradient of $0.3^{\circ} \mathrm{C} / 100 \mathrm{~m}$. This gradient reveals that the groundwater in the well is not thermally equilibrated with the rock matrix, which has a mean geothermal gradient of about $3{ }^{\circ} \mathrm{C} / 100 \mathrm{~m}$ (BRGM and ADEME (2005); and BRGM 2005). The reduced temperature gradient observed in the water column is likely the result of vertical movement of groundwater through the well.

The annual mean air temperature in the area is $10.7 \pm$ $0.6^{\circ} \mathrm{C}$ (Station Trappes of Meteo-France: observation period from 1991 to 2000), which constrains the water temperature at the upper part of the screen $(25 \mathrm{~m} \mathrm{bgl})$

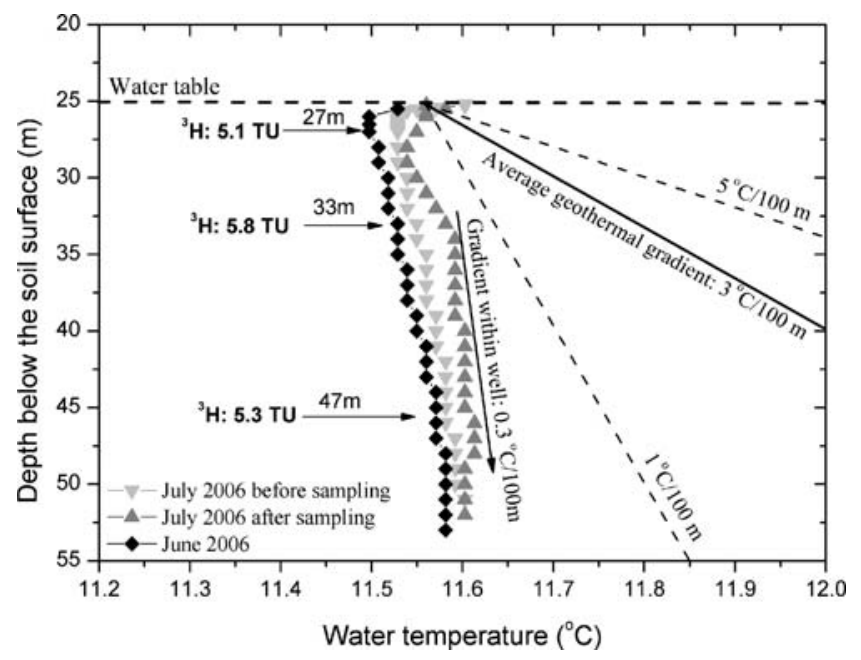

Fig. 4 Water temperature profiles measured in well SM on two different dates (June and July, 2006). For July 2006, the temperature profiles measured before and after using the low-flow pumping method are shown. The average geothermal gradient in rocks $\left(3^{\circ} \mathrm{C} /\right.$ $100 \mathrm{~m}$ ), with the typical range of variation for France (between 1 and $\left.5^{\circ} \mathrm{C} / 100 \mathrm{~m}\right)$, and the water gradient $\left(0.3^{\circ} \mathrm{C} / 100 \mathrm{~m}\right)$ are represented. The ${ }^{3} \mathrm{H}$ activities measured at the selected depth within the screen are shown 
to about $11.5^{\circ} \mathrm{C}$ based on a geothermal gradient of $3^{\circ}$ $\mathrm{C} / 100 \mathrm{~m}$ in the unsaturated zone of the aquifer (Gosnold et al. 1997). This estimate fits to the values measured at the upper part of the screen $\left(11.5-11.6^{\circ} \mathrm{C}\right.$, see Fig. 4). An agreement that further supports the hypothesis of a downward water flow within the well.

\section{Conclusions}

Simple field experiments confirmed the existence of ambient vertical flow in a LSW which is located in an area of the Fontainebleau Sands Aquifer with very homogeneous hydrogeological conditions. This preferential transport of water through the well has strong implications, for example, for the interpretation of the environmental tracer data. Since the groundwater stratification within and in the surroundings of the well is modified by the AVF of water; samples collected from the well would provide unreliable and potentially misleading results of aquifer properties. The application of the commonly used lumped parameter models might result in a biased understanding of the real groundwater age distribution in the aquifer.

The study highlights the possibility of using temperature $\operatorname{logs}$ for identifying the existence of AVF in wells. This approach is in general cheap and does not require further interpretations. It is shown that tracers with large stratification of depth such as ${ }^{3} \mathrm{H}$, are excellent tools for detecting the direction of the vertical flow. However, for the same reason, their use for investigating aquifer properties may be restricted.

Special care must be taken when planning tracer investigations, even in aquifers with very homogeneous hydrogeological conditions. In recent years, several sampling strategies have been proposed to avoid the misrepresentations discussed above (Nielsen 2005). The sampling techniques have to be adopted according to the objectives of the investigation, the hydrogeological conditions of the site and the design of the borehole. Between the most common solutions we could mention, for example, the drilling of precise monitor boreholes open to selected depths or short-screened boreholes. This solution is, in general, expensive, as several boreholes will be needed to cover different depths, and requires other testing. Other researchers prefer the use of "packers" in already drilled boreholes, but special care must be taken to avoid mixing via percolation of water through the packing material.

In order to reduce the effects of the AVF within boreholes, special attention must be paid in designing and constructing the wells. If a detailed characterization of the aquifer system is needed, then it would be advisable to use multiple-level sampling in short-screened wells instead of using the full screen sampling in LSWs. However, this solution is generally expensive.

\section{References}

Bariteau A (1996) Modélisation géochimique d'un aquifère: la nappe de l'Oligocène en Beauce et l'altération des Sables de Fontainebleau [Geochemical modeling of an aquifer: the Oligocene layer in Beauce and the Fontainebleau sands formation]. PhD Thesis, Ecole des Mines de Paris, France

Barraclough PB, Tinker PB (1982) The determination of ionic diffusion coefficients in field soils. II. Diffusion of bromide ions in undisturbed soil cores. J Soil Sci 33:13-24

BRGM (2005) Géothermie très basse et basse énergie: Une énergie du développement durable [Very low geothermal energy, and low energy: energy for sustainable development]. Fiches scientifiques "Les enjeux des géosciences" 10 (BRGM), Orléans, France

BRGM and ADEME (2005) Geothermal perspectives. BRGM, Orléans, ADEME, Paris. Available at http://www.geothermieperspectives.fr/. Cited January 2008

Cook PG, Solomon DK (1995) Transport of atmospheric trace gases to the water table: implications for groundwater dating with chlorofluorocarbons and krypton-85. Water Resour Res 31 (2):263-270

Corcho Alvarado JA, Purtschert R, Hinsby K et al $(2005){ }^{36} \mathrm{Cl}$ in modern groundwater dated by a multi tracer approach $\left({ }^{3} \mathrm{H} /{ }^{3} \mathrm{He}\right.$, $\mathrm{SF}_{6}, \mathrm{CFC}-12$ and ${ }^{85} \mathrm{Kr}$ ): a case study in Quaternary sand aquifers in the Odense Pilot River Basin, Denmark. Appl Geochem 30(3):599-609

Corcho Alvarado JA, Purtschert R, Barbecot F et al (2007) Constraining the age distribution of highly mixed groundwater using ${ }^{39} \mathrm{Ar}$ : a multiple environmental tracer $\left({ }^{3} \mathrm{H} /{ }^{3} \mathrm{He},{ }^{85} \mathrm{Kr}\right.$, ${ }^{39} \mathrm{Ar}$ and ${ }^{14} \mathrm{C}$ ) study in the semi-confined Fontainebleau Sands aquifer (France). Water Resour Res 43, W03427. doi:10.1029/ 2006WR005096

Church PE, Granato GE (1996) Bias in ground-water data caused by well-bore flow in long-screen wells. Ground Water 34 (2):262-273

Einarson M (2005) Multilevel groundwater monitoring. In: Nielsen DM (ed) Practical handbook of environmental site characterization and ground-water monitoring. CRC, Boca Raton, FL, pp $807-882$

Elci A, Molz FJ, Waldrop WR (2001) Implications of observed and simulated ambient flow in monitoring wells. Ground Water 36 (6):853-862

Elci A, Flach GP, Molz FJ (2003) Detrimental effects of natural vertical head gradients on chemical and water level measurements in observation wells: identification and control. J Hydrol 281(1-2):70-81

Ekwurzel B, Schlosser P, Smethie M Jr et al (1994) Dating of shallow groundwater: comparison of the transient tracers ${ }^{3} \mathrm{H} /{ }^{3} \mathrm{He}$, chlorofluorocarbons and ${ }^{85} \mathrm{Kr}$. Water Resour Res 30 (6): $1693-1708$

Engesgaard P, Høgh JK, Molson J et al (1996) Large-scale dispersion in a sandy aquifer: simulation of subsurface transport of subsurface transport of environmental. Water Resour Res 32 (11):3253-3266

Fetter CW (2001) Applied hydrogeology. Prentice Hall, Englewood Cliffs, NJ

Gosnold WD, Todhunter PE, Schmidt W (1997) The borehole temperature record of climate warming in the mid-continent of North America. Glob Planet Change 15:33-45

Gaye CB, Edmunds WM (1996) Groundwater recharge estimation using chloride, stable isotopes and tritium profiles in the sands of northwestern Senegal. Environ Geol 27:246-251

IAEA/WMO (2001) The Global Network of Isotopes in Precipitation database. Available at http://isohis.iaea.org. Cited November 2007

Maloszewski P, Stichler W, Zuber A (2004) Interpretation of environmental tracers in groundwater systems with stagnant water zones. Isot Environ Health Stud 40(1):21-33

Martin-Hayden JM, Robbins GA (1997) Plume distortion and apparent attenuation due to concentration averaging in monitoring wells. Ground Water 35(2):339-347 
Mégnien C (1979) Hydrogéologie du centre du Bassin de Paris. Mémoire BRGM 98, BRGM, Orléans, France, 552 pp

Ménillet $\mathrm{F}$ (1988) Meulières, argiles à meulières et meuliérisation: historique, évolution des termes et hypothèses génétiques [Meulières, Clay meulières and meuliérisation: historical evolution of the terms and assumptions genetic]. Bull Inf Géol Bassin Paris 25(4):71-79

Mercier R (1981) Inventaire des ressources aquifères et vulnérabilité des nappes du département des Yvelines [Inventory of aquifer resources and groundwater vulnerability of the department of Yvelines]. Rapport BRGM 81SGN348IDF, Service géologique régional Île de France, Paris, France

Millington RJ (1959) Gas diffusion in porous media. Science 130:100-102

Nielsen DM (2005) Practical handbook of environmental site characterization and ground-water. CRC, Boca Raton, FL

Ozyurt NN, Bayari CS (2003) LUMPED: a Visual Basic code of lumped-parameter models for mean residence time analyses of groundwater systems. Comput Geosci 29(1):79-90

Pfister M, Rybach L (1996) High-resolution temperature logging in shallow drillholes for the determination of terrestrial heat flow: field samples and analysis. Tectonophysics 257:93-99

Price M, Williams AT (1993) A pumped double-packer system for use in aquifer evaluation and groundwater sampling. Water Maritime Ener J 1(101):85-92

Rampon G (1965) Etat de la documentation sur les ouvrages souterrains implantés sur les feuilles topographiques de Nogent le Roi-Rambouillet et synthèse hydrogéologique provisoire [State of the documentation on the underground Structures located on the leaves topographic Nogent le -Roi-Rambouillet and provisional hydrogeological synthesis]. Rapport du BRGM DSGR 65.A7, Service géologique régional du Bassin de Paris, Paris, France

Reilly TE, Franke OL, Bennett GD (1989) Bias in groundwater samples caused by wellbore flow. J Hydraul Eng 115(2):270-276

Roether W (1967) Estimating the tritium input to groundwater from wine samples: groundwater and direct run-off contribution to Central European surface waters. In: Isotopes in hydrology. IAEA, Vienna, pp 73-79

Rueedi J, Brennwald MS, Purtschert R, Beyerle U, Hofer M, Kipfer $\mathrm{R}$ (2005) Estimating amount and spatial distribution of groundwater recharge in the Illumeden basin (Niger) based on $3 \mathrm{H}, 3 \mathrm{He}$, and CFC-11 measurements. Hydrol Proc 19 (17):3285-3298

Sanford WE, Shropshire RG, Solomon DK (1996) Dissolved gas tracers in groundwater: simplified injection, sampling, and analysis. Water Resour Res 32(6):1635-1642

Schlosser P, Stute M, Dorr H, Sonntag C, Munnich KO (1988) Tritium $/{ }^{3} \mathrm{He}$ dating of shallow groundwater. Earth Planet Sci Lett 89:353-362

Schlosser P, Stute M, Sonntag C, Munnich KO (1989) Tritiogenic ${ }^{3} \mathrm{He}$ in shallow groundwater. Earth Planet Sci Lett 94:245-256

Schneider V (2005) Apports de l'hydrodynamique et de la géochimie à la caractérisation des nappes de l'Oligocène et de l'Eocène (sud-ouest du Bassin de Paris) [Contributions of the hydrodynamics and geochemistry to the characterization of the Oligocene and the Eocene aquifers (south-west of Paris Basin)], $\mathrm{PhD}$ Thesis, Université Paris-Sud, U.F.R. Scientifique d'Orsay, Paris, France

Vernoux JF, Le Nindre YM, Martin JC (2001) Relations napperivière et impact des prélèvements d'eau souterraine sur le débit des cours d'eau dans le bassin de la Juine et de l'Essonne [Relations aquifer-river, and the impact of groundwater withdrawals on the flow of rivers in the basin of Juine and Essonne]. Rapport BRGM (RP-50637-FR), BRGM, Orléans, France

Weissmann GS, Zhang Y, LaBolle EM, Fogg GE (2002) Dispersion of groundwater age in an alluvial aquifer system. Water Resour Res 38(10): 1198

Zhang Y, Fogg GE (2002) Dispersion of groundwater age as a function of heterogeneity and well screen length in heterogeneous media. Fall Meeting of the American Geophysical Union, AGU, Washington, DC, (abstract)

Zinn BA, Konikow LF (2007) Effects of intraborehole flow on groundwater age distribution. Hydrogeol J 15(4):633-643

Zuber A (1986) Mathematical models for the interpretation of environmental radioisotopes in groundwater systems. In: Fritz P, Fontes JCh (eds) Handbook of environmental isotope geochemistry, vol 2: the terrestrial environment $\mathrm{B}: 1-59$

Zuber A, Maloszewski P (2001) Lumped-parameter models. In: Environmental isotopes in the hydrological cycle, vol 6: modeling. Tech. Doc. Hydrol. 39, UNESCO/IAEA, Vienna, pp 5-35 